\title{
Estimation of Ecosystem Services Provided by Street Trees in Kyoto, Japan
}

\author{
Xiaoyang Tan ${ }^{1, *(1)}$, Satoshi Hirabayashi ${ }^{2} \mathbb{C}$ and Shozo Shibata ${ }^{1}$ (I) \\ 1 Graduate School of Global Environmental Studies, Kyoto University, Kyoto 606-8501, Japan; \\ shibata.shozo.6n@kyoto-u.ac.jp \\ 2 The Davey Institute, 5 Moon Library, SUNY-ESF, Syracuse, NY 13210, USA; satoshi.hirabayashi@davey.com \\ * Correspondence: tang.xiaoyang.26a@st.kyoto-u.ac.jp
}

\section{check for}

updates

Citation: Tan, X.; Hirabayashi, S.; Shibata, S. Estimation of Ecosystem Services Provided by Street Trees in Kyoto, Japan. Forests 2021, 12, 311. https://doi.org/10.3390/f12030311

Academic Editor: Paletto Alessandro

Received: 7 January 2021

Accepted: 5 March 2021

Published: 7 March 2021

Publisher's Note: MDPI stays neutral with regard to jurisdictional claims in published maps and institutional affiliations.

Copyright: (c) 2021 by the authors. Licensee MDPI, Basel, Switzerland. This article is an open access article distributed under the terms and conditions of the Creative Commons Attribution (CC BY) license (https:// creativecommons.org/licenses/by/ $4.0 /)$.
Abstract: Street trees are integral components of urban green infrastructure. The importance of benefits provided by street trees has motivated the development of various tools to quantify the value of ecosystem services. The i-Tree Eco is a widely applied method for quantifying urban forest structure, ecosystem services, and values. Since its first release in 2006, i-Tree Eco has been successfully utilized in over 100 countries around the world. This study described one of the first applications of the i-Tree Eco international project in Kyoto, Japan, by customizing the models and parameters to enhance the accuracy of analysis results. Kyoto's street trees are prominently dominated by Ginkgo (Ginkgo biloba L.), Trident Maple (Acer buergerianum Miq.), Japanese Zelkova (Zelkova serrata (Thunb.) Makino.), Tuliptree (Liriodendron tulipifera L.), Flowering dogwood (Cornus florida L.), London Planetree (Platanus $\times$ acerifolia), Plum/cherry (Prunus spp.), and Weeping willow (Salix babylonica), which account for $92 \%$ of the 1230 sample trees and deliver ecosystem service benefits at US\$71,434.21 annually or US\$58.07/tree/year. The annual value of each function was estimated at US $\$ 41.34 /$ tree for carbon storage and sequestration, US $\$ 3.26 /$ tree for stormwater runoff reduction, US $\$ 11.80 /$ tree for adverse health mitigation effects, and US $\$ 1.67 /$ tree for energy savings. The street tree species of Kyoto city that produce the highest average annual benefits are among the largest trees currently in the population, including $P . \times$ yedoensis (US\$225.32/tree), Z. serrata (US\$123.21/tree), S. babylonica (US\$80.10/tree), and $P . \times$ acerifolia (US $\$ 65.88 /$ tree). Our results demonstrated a comprehensive understanding of street trees benefits for Kyoto city, providing baseline information for decision-makers and managers to make effective urban trees management decisions, developing policy, and setting priorities.

Keywords: ecosystem services; i-Tree Eco customization; street trees; tree benefit value

\section{Introduction}

Urbanization, one of the most transformative trends in the 21st century, is accompanied by increasing populations and socioeconomic activities concentrated in cities. In recent decades, urbanization adversely impacts urban ecosystems and environmental quality through phenomena such as the urban heat island effect, air pollution, and alterations to hydrological systems [1,2]. Since the publication of the Millennium Ecosystem Assessment (MEA) [3] and The Economics of Ecosystems and Biodiversity (TEEB) report [4], ecosystem services have gained broader attention in many parts of the world [5,6]. Ecosystem services (hereafter referred to as ES) refer to the life-support functions performed by natural ecosystems that underpin humanity's most fundamental sources of well-being [7]. The strong desire to develop a sustainable urban environment that delivers the ES has encouraged policymakers and scholars to direct their attention to evaluating the potential of urban trees to mitigate environmental degradation [1].

Street trees are recognized as integral components of urban ecosystems, which can improve environmental quality by providing significant ecological benefits [8]. There 
is a growing body of literature that highlights the ES provided by street trees, such as storing carbon $[9,10]$, regulating the air quality [11], as well as improving the streetscape and amenity [8,12]. Street trees also appear to be a feasible option for ameliorating the urban heat-island effect [13-15]. Moreover, trees play an important role in urban catchment hydrology through canopy interception and soil infiltration of rainfall $[16,17]$.

Despite the high level of scholarly recognition of street tree benefits, many local governments fail to recognize the importance of street trees due to unknown economic values, while the costs of damage by trees such as leaf litter and infrastructure damage are widely reported $[8,18]$. Evidence of the economic worth of street trees in monetary terms is essential for decision-makers as it offers baseline information for long-term street-tree management and maintenance practices [19]. To understand the potential ES more fully and maximize the benefits of urban trees, several urban forest models have been developed and implemented in different cities $[5,20]$. The most frequently used model is the i-Tree software developed by the US Forest Service (www. itreetools.org), which provides a methodology using field data to assess the biophysical state and economic value of urban and community forests. Many studies based on the i-Tree software have demonstrated that the monetary values of ecosystem benefits provided by street trees exceed the annual cost of tree management. A study conducted in New York and Indianapolis showed that every \$1 spent per year on tree-care-related expenditure resulted in US\$5.6 and US\$6.09 worth of ecosystem benefits, respectively, which was a greater economic benefit than that reported from any other city to date [21,22].

Although i-Tree tools have been extensively used across the US and European countries over the past 10 years, limited research using this method has been conducted in other parts of the world [1]. There are still uncertainties in applying US-based ES and associated benefit quantification models to other countries without appropriate modifications. For example, the fact that the acquisition of site-specific parameters is unavailable or insufficient will indicate possible inaccuracies of the results [5,23]. To improve model functionality in other countries, Hirabayashi et al. [24,25] conducted pilot studies in Japan, in which the accuracy of analysis results was enhanced by largely customizing the models and their parameters.

This study describes the application of i-Tree Eco with customized models and parameters for monetarization of the street tree benefits in Kyoto, Japan. The objectives of this study were as follows: (1). To demonstrate the procedure for implementing the i-Tree Eco project in Japan, including collecting all relevant data sources and explaining customizations conducted for each model. (2). To present objective data on the value of ecosystem services provided by street trees in Kyoto city as baseline data for evaluating returns on tree management investment. (3). To appeal for a better understanding of street trees as green assets, which could help ensure adequate tree maintenance and lead to future improvements in management and plans.

\section{Materials and Methods}

\subsection{The City of Kyoto}

Kyoto City, the capital of Kyoto Prefecture, is located in the central part of Honshu, Japan (Figure 1), which has a humid subtropical climate with hot, humid summers (JuneAugust), and cold, dry winters (December-February). Due to its basin topography, Kyoto experiences the most severe summer heat in Japan, with a mean daily maximum temperature of around $37^{\circ} \mathrm{C}$ in August [26]. In the central urban area of Kyoto City, given the limited large green spaces, street trees are recognized as an irreplaceable green infrastructure for mitigating urban heat island effects and providing critical ecological connectivity to promote faunal abundance and diversity [27]. 


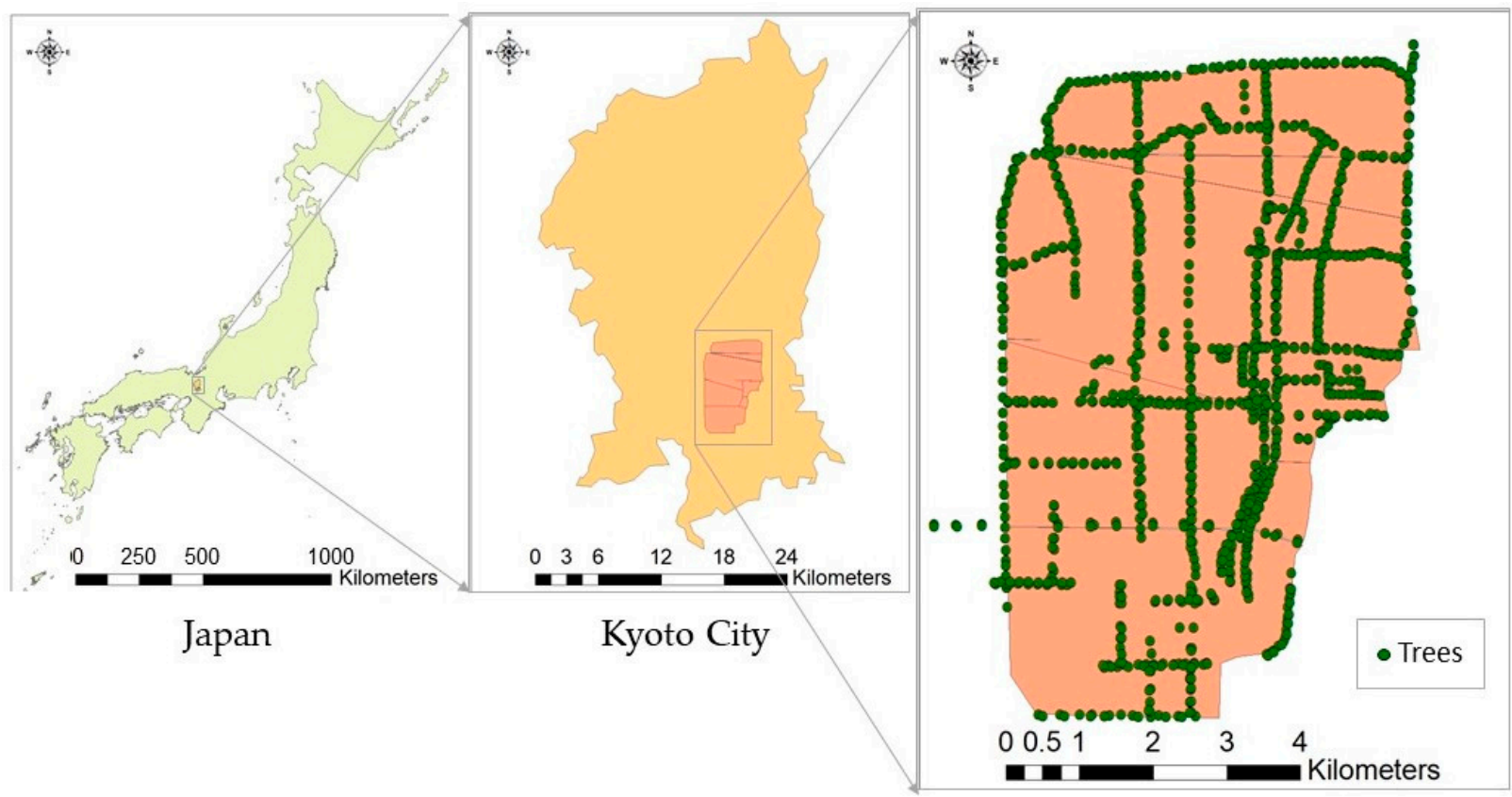

Survey Area: 1230 street trees

Figure 1. Location of sample street trees in the urban area of Kyoto City.

\subsection{Collecting Tree Data}

With reference to the basic plan for greening Kyoto City, the green corridor zone was selected as the research area, which embraces the east to west extent from Shirakawa-Dori Street to Nishioji-Dori Street and stretches north to south from Kitayama-Dori Street to Jyujo-Dori Street [27]. The total area is $48.85 \mathrm{~km}^{2}$, covering seven wards with a total population of 451,462 [28]. Field sampling of 1230 street trees was conducted from June to October 2018. Approximately $10 \%$ of street trees on the 41 streets were sampled at equal distances to generate the tree inventory (Figure 1). Field measurements were performed in accordance with the i-Tree Eco field manual [29]. Tree species and adjacent land use were verified in the field. Health condition, crown light exposure, and percent crown missing were estimated by one person by visual inspection. Total tree height, height to crown base, diameter at breast height (DBH), crown width was measured using a Trupulse 360 laser rangefinder (Laser Technology, Inc., CO, USA) and a diameter tape.

\subsection{Estimation of Ecosystem Services by i-Tree Eco}

i-Tree Eco estimates urban and community forest features such as biomass and leaf area and then, based on these properties, quantifies the ES provided by the forests. The system comprises of three components: model codes written in computer languages, parameters for the models (e.g., coefficients in model equations), and input data (e.g., weather data).

Currently, for a total of about 40 countries officially supported, input data such as tree species, weather, upper air, air quality, and location-related data (such as coordinates and population) are stored in the i-Tree server computers. Using these data, the analyses can be conducted in these 40 countries, with only the tree data prepared by users. Because the species, weather, and upper-air data stored in the server are globally available, even users in other countries can use i-Tree Eco with their local location, air quality, and precipitation data uploaded to the server via i-Tree Database (ITDB) (www.database.itreetools.org). However, this path only enables users to use their local data; it is impossible for the model itself and parameters to be modified for their use in their own countries.

The ES provided by trees that i-Tree Eco can estimate include (1) carbon storage and sequestration, (2) air pollution removal, (3) human health effects associated with air 
pollution removal, (4) heating and cooling energy savings in houses, and (5) stormwater runoff avoided. The models for (1), (2), and (5) are readily applicable to countries other than the US using the local data that are made available with ITDB. On the other hand, since the models for (3) and (4) were originally developed based on the methods and data applicable to the US only, the application of these models to countries outside the US is very limited.

This study estimated (1) to (5) based on street tree measurements in Kyoto. The i-Tree Eco's limitations existing outside the US were greatly reduced by modifying the model codes, as well as parameters with the cooperation of an i-Tree developer. Table 1 presents the input data/parameters for each model with a notation of customization conducted in this study, and the following sections explain each model and customizations conducted for models of (3) and (5).

Table 1. Model input data and parameters used for i-Tree Eco run for Kyoto city.

\begin{tabular}{|c|c|c|c|c|}
\hline Model & Input Data/Parameter & Value/ID/Monitor & Data Year & Reference \\
\hline $\begin{array}{l}\text { Carbon } \\
\text { Storage/Sequestration }\end{array}$ & Social cost of carbon ${ }^{a}$ & $51.2 \mathrm{US} \$ / \mathrm{t}$ & 2018 & IWG, 2016 [30] \\
\hline \multirow[t]{32}{*}{ Air Pollutant Removal } & Latitude $^{b}$ & 35.0117 & - & - \\
\hline & Longitude $^{b}$ & 135.768 & - & - \\
\hline & Time zone ${ }^{b}$ & $\mathrm{UTC}+9$ & - & - \\
\hline & Leaf-on date ${ }^{b}$ & Apr. 4th & $1981-2010$ & JMA, 2018 [31] \\
\hline & Leaf-off date ${ }^{b}$ & Nov. 18th & $1981-2010$ & JMA, 2018 [31] \\
\hline & Surface weather ${ }^{\text {a }}$ & 477590: Kyoto & 2015 & NCEI, 2019 [32] \\
\hline & Upper air ${ }^{\text {a }}$ & 47778: Shionomisaki & 2015 & ESRL, 2019 [33] \\
\hline & Solar radiation ${ }^{c}$ & 26104060: Mibu & 2015 & NIES, 2019 [34] \\
\hline & Net radiation ${ }^{c}$ & $\begin{array}{l}\text { 28204150: } \\
\text { Hamakoushien }\end{array}$ & 2015 & NIES, 2019 [34] \\
\hline & Precipitation ${ }^{b}$ & 28214010: Yoriaihiroba & 2015 & NIES, 2019 [34] \\
\hline & \multirow{5}{*}{ CO concentration ${ }^{b}$} & 26104510: Jihaioomiya & 2010-2015 & NIES, 2019 [34] \\
\hline & & 26107510: Jihaiminami & 2010-2015 & NIES, 2019 [34] \\
\hline & & 26101010: Kita & $2010-2015$ & NIES, 2019 [34] \\
\hline & & 26102510: & $2010-2015$ & NIES, 2019 [34] \\
\hline & & Jihaikamigyou & & \\
\hline & \multirow{7}{*}{$\mathrm{NO}_{2}$ concentration ${ }^{\mathrm{b}}$} & 26103010: Sakyou & 2010-2015 & NIES, 2019 [34] \\
\hline & & 26104010: & $2010-2015$ & NIES, 2019 [34] \\
\hline & & Kyoutoshiyakusho & & \\
\hline & & 26104060: Mibu & 2010-2015 & NIES, 2019 [34] \\
\hline & & 26104510: Jihaioomiya & 2010-2015 & NIES, 2019 [34] \\
\hline & & 26107510: Jihaiminami & 2010-2015 & NIES, 2019 [34] \\
\hline & & 26101010: Kita & $2010-2015$ & NIES, 2019 [34] \\
\hline & \multirow{5}{*}{$\mathrm{O}_{3}$ concentration ${ }^{b}$} & 26103010: Sakyou & 2010-2015 & NIES, 2019 [34] \\
\hline & & 26104010: & $2010-2015$ & NIES, 2019 [34] \\
\hline & & Kyoutoshiyakusho & & \\
\hline & & 26104060: Mibu & 2010-2015 & NIES, 2019 [34] \\
\hline & & $\begin{array}{l}\text { 26102510: } \\
\text { Jihaikamigyou }\end{array}$ & 2010-2015 & NIES, 2019 [34] \\
\hline & \multirow[t]{4}{*}{$\mathrm{PM}_{2.5}$ concentration ${ }^{\mathrm{b}}$} & $\begin{array}{l}\text { 26104010: } \\
\text { Kyoutoshiyakusho }\end{array}$ & 2010-2015 & NIES, 2019 [34] \\
\hline & & 26104060: Mibu & 2010-2015 & NIES, 2019 [34] \\
\hline & & 26104510: Jihaioomiya & 2010-2015 & NIES, 2019 [34] \\
\hline & & 26107510: Jihaiminami & $2010-2015$ & NIES, 2019 [34] \\
\hline & $\mathrm{SO}_{2}$ concentration $\mathrm{b}$ & 26104060: Mibu & 2010-2015 & NIES, 2019 [34] \\
\hline \multirow[t]{4}{*}{ Human health effects } & Population $\mathrm{b}$ & 451,462 (total) & 2015 & Kyoto City, 2018 [35] \\
\hline & Medical expense $^{c}$ & $46 \%$ of the US & 2018 & OECD, 2019a [36] \\
\hline & Household income $^{c}$ & $65 \%$ of the US & - & OECD, 2019b [37] \\
\hline & $\begin{array}{l}\text { Value of a statistical } \\
\text { life }{ }^{c}\end{array}$ & $3,909,090.91$ US\$ & $1991-2007$ & Miyazato, 2010 [38] \\
\hline
\end{tabular}


Table 1. Cont.

\begin{tabular}{|c|c|c|c|c|}
\hline Model & Input Data/Parameter & Value/ID/Monitor & Data Year & Reference \\
\hline \multirow[t]{15}{*}{ Energy savings } & Building ${ }^{c}$ & & & GSI, 2018 [39] \\
\hline & Tree/building cover ${ }^{c}$ & $52 \%$ & & GSI, 2018 [39] \\
\hline & Years constructed ${ }^{\mathrm{c}}$ & - & - & Kyoto pref., 2018 [40] \\
\hline & Number of houses ${ }^{c}$ & 692,800 (total in Kyoto) & 2015 & Kyoto pref., 2018 [40] \\
\hline & $\mathrm{CO}_{2}$ emission & & & \\
\hline & Coefficient & & & \\
\hline & Electricity ${ }^{\mathrm{c}}$ & $0.509 \mathrm{~kg}-\mathrm{CO}_{2} / \mathrm{kWh}$ & 2015 & MoE, 2019 [41] \\
\hline & Natural gas ${ }^{c}$ & $53.70 \mathrm{~kg}-\mathrm{CO}_{2} / \mathrm{MBTU}$ & 2015 & $\begin{array}{l}\text { Daigas Group, } \\
2019 \text { [42] }\end{array}$ \\
\hline & Heating oil ${ }^{\mathrm{c}}$ & $71.53 \mathrm{~kg}-\mathrm{CO}_{2} / \mathrm{MBTU}$ & 2015 & MoE, 2019 [43] \\
\hline & $\mathrm{LPG}^{\mathrm{c}}$ & $62.25 \mathrm{~kg}-\mathrm{CO}_{2} / \mathrm{MBTU}$ & 2015 & Japan LPGA, 2019 [44] \\
\hline & Price & & & \\
\hline & Electricity ${ }^{b}$ & $0.23 \mathrm{US} \$ / \mathrm{kWh}$ & 2015 & KEPCO, 2018 [45] \\
\hline & Natural gas ${ }^{b}$ & $33.68 \mathrm{US} \$ / \mathrm{MBTU}$ & 2015 & $\begin{array}{l}\text { Daigas Group, } \\
2019 \text { [46] }\end{array}$ \\
\hline & Heating oil ${ }^{b}$ & $24.20 \mathrm{US} \$ / \mathrm{MBTU}$ & 2015 & Agency NRE, 2019 [47] \\
\hline & $\mathrm{LPG}^{\mathrm{b}}$ & $67.11 \mathrm{US} \$ / \mathrm{MBTU}$ & 2015 & $\begin{array}{l}\text { Oil Info. Center, } \\
2019[48]\end{array}$ \\
\hline \multirow[t]{4}{*}{ Avoided runoff } & Surface weather ${ }^{a}$ & 477590: Kyoto & 2015 & NCEI, 2019 [32] \\
\hline & Precipitation $\mathrm{b}$ & 28214010: Yoriaihiroba & 2015 & NIES, 2019 [34] \\
\hline & Impervious cover ${ }^{c}$ & $80.57 \%$ & 2014-2016 & JAXA, 2019 [49] \\
\hline & $\begin{array}{l}\text { Stormwater control } \\
\text { cost }^{d}\end{array}$ & $2.36 \mathrm{US} \$ / \mathrm{m}^{3}$ & 2007 & Vargas, et al., 2007 [50] \\
\hline
\end{tabular}

${ }^{a}$ : Globally applicable data/parameter; ${ }^{b}$ : Replaceable with local data/parameter via i-Tree Database; also replaced in this study; ${ }^{c}$ : Customized in this study; ${ }^{\mathrm{d}}$ : Parameter for the US and employed in this study.

\subsubsection{Carbon Storage and Sequestration}

It was necessary to identify the correspondence between tree species found in Kyoto city and those in i-Tree Eco's species database to calculate carbon storage and sequestration into trees. Other than that, no customization for the codes, parameters, and data was necessary. Based on the property of each tree species, dry biomass for woody parts as well as leaves was calculated using the methods described in Nowak et al. [51,52]. Half of the dry biomass of trees was estimated as the carbon stored in trees. The growth of a tree was estimated for each tree species based on the health condition and planted site characteristics (e.g., crown light exposure) of the tree. The gross amount of carbon sequestered annually into a tree was then calculated from the difference in estimates of carbon storage between the current and next year [51,52].

\subsubsection{Air Pollution Removal}

Based on tree structures such as tree cover and evergreen percent in the study area as well as the leaf area index (LAI) estimated with i-Tree Eco, the removal of carbon monoxide $(\mathrm{CO})$, nitrogen dioxide $\left(\mathrm{NO}_{2}\right)$, ozone $\left(\mathrm{O}_{3}\right)$, particulate matter less than $2.5 \mu \mathrm{m}$ $\left(\mathrm{PM}_{2.5}\right)$, and sulfur dioxide $\left(\mathrm{SO}_{2}\right)$ were estimated as described by Hirabayashi et al. [53,54] and Nowak et al. [55]. Input data for the model (i.e., surface weather, upper air, and air pollutant data) from the local monitoring stations were employed here (Table 1). Although the parameters for the model were not optimized, the model itself was optimized to use local measurements of solar and net radiation rather than calculating these based on the extraterrestrial solar constant, coordinate, and other atmospheric properties (e.g., ozone depth and albedo), which is the default model implementation in i-Tree Eco.

\subsubsection{Human Health Effects Associated with Air Pollution Removal}

i-Tree Eco estimates avoided adverse health incidences and costs associated with changes in $\mathrm{NO}_{2}, \mathrm{O}_{3}, \mathrm{PM}_{2.5}$, and $\mathrm{SO}_{2}$ concentration due to the removal of pollution by 
trees [55,56] with BenMAP [57] incorporated into i-Tree Eco. BenMAP was developed by the US Environmental Protection Agency by consolidating the human medical records and air quality measurements across the US with the knowledge gained from statistical analyses of those data.

Based on seven concentration change metrics, 13 adverse health endpoints can be analyzed with BenMAP. The concentration change metrics include the annual mean of daily $1 \mathrm{~h}$ maximum (1Max), daily mean for 8-10 a.m. (3Mean), daily mean for 6-9 a.m. (4Mean), daily maximum for $8 \mathrm{~h}$ moving average (8Max), daily mean for 9 a.m-4 p.m. (8Mean), daily mean (24Mean), and the quarterly mean of the daily mean (24MeanQ). The 13 adverse health endpoints analyzed include Acute Respiratory Symptoms (ARS), Emergency Room Visits (ERV), and Hospital Admissions, Respiratory (HAR) caused by exposure to $\mathrm{NO}_{2}, \mathrm{O}_{3}, \mathrm{PM}_{2.5}$, and $\mathrm{SO}_{2}$, Asthma Exacerbations (AE) caused by exposure to $\mathrm{NO}_{2}, \mathrm{PM}_{2.5}$, and $\mathrm{SO}_{2}$, mortality $(\mathrm{M})$ caused by exposure to $\mathrm{O}_{3}$ and $\mathrm{PM}_{2.5}$, Acute/Chronic Bronchitis (AB/CB), Acute Myocardial Infarction (AMI), Hospital Admissions, Cardiovascular (HAC), Upper/Lower Respiratory Symptoms (URS/LRS), and Work Loss Days (WLD) caused by exposure to $\mathrm{PM}_{2.5}$, and school loss days (SLD) caused by exposure to $\mathrm{O}_{3}$.

In BenMAP, correlations between changes in concentration metrics of air pollutant, $\Delta C_{i}$, and changes in adverse health incidences, $\Delta I_{i}$ for the age group population, $P_{i}$, and accompanying changes in medical expenses, $\Delta V_{i}$ are defined with 85 health effect functions for each county in the US, where i represents a function number. For example, $i=58$ defines the relationship between the change in $1 \mathrm{Max}$ of $\mathrm{NO}_{2}$ and the change in HAR incidences and medical expenses in the age group 0-14 years old. In Los Angeles County, California, where the population $\mathrm{P}_{\mathrm{i}}$ of the age group 0-14 years old is the largest in the US (about 2 million people), $\Delta C_{58}=12.3 \mu \mathrm{g} / \mathrm{m}^{3}$, whereas $\Delta \mathrm{I}_{58}=228$ and $\Delta \mathrm{V}_{58}=\mathrm{US} \$ 663$ million.

For each county, $\mathrm{P}_{\mathrm{i}}$ was derived from the 2010 US Census, $\Delta \mathrm{C}$ is the change in the metrics in each county between the maximum (baseline year) and minimum (control year) concentrations within the period of 2000-2007.

When integrating BenMAP's 85 health effect functions into i-Tree Eco, the incidence multiplier, $\mathrm{IM}_{\mathrm{i}}$ (case/ppb/person or case $/ \mu \mathrm{g} / \mathrm{m}^{3} /$ person), which is the incidence per unit change in concentration per person for each county, was estimated from Equation1 below. Similarly, the value multiplier, $\mathrm{VM}_{\mathrm{i}}$ (US\$/ppb/person or US\$/ $\mu \mathrm{g} / \mathrm{m}^{3} /$ person), which is medical expenses per unit change in concentration per person for each county, was estimated from Equation (2).

$$
\begin{aligned}
\mathrm{IM}_{\mathrm{i}} & =\frac{\Delta \mathrm{I}_{\mathrm{i}}}{\mathrm{P}_{\mathrm{i}} \cdot \Delta \mathrm{C}_{\mathrm{i}}} \\
\mathrm{VM}_{\mathrm{i}} & =\frac{\Delta \mathrm{V}_{\mathrm{i}}}{\mathrm{P}_{\mathrm{i}} \cdot \Delta \mathrm{C}_{\mathrm{i}}}
\end{aligned}
$$

This integration allowed for the calculation of reduction in adverse health incidence $(\Delta \mathrm{I})$ and reduction in medical expenses $(\Delta \mathrm{V})$ based on the $\Delta \mathrm{C}_{\mathrm{i}}$ provided by the trees, $\mathrm{P}_{\mathrm{i}}$, and these multipliers. For example, reduction in $\mathrm{HAR}$ associated with $\mathrm{NO}_{2}$ for 0 - to 99-years-olds can be calculated as follows:

$$
\Delta \mathrm{I}=\mathrm{IM}_{58} \cdot \mathrm{P}_{58} \cdot \Delta \mathrm{C}_{58}+\mathrm{IM}_{59} \cdot \mathrm{P}_{59} \cdot \Delta \mathrm{C}_{59}+\mathrm{IM}_{64} \cdot \mathrm{P}_{64} \cdot \Delta \mathrm{C}_{64}
$$

where $\mathrm{P}_{58}, \mathrm{P}_{59}$, and $\mathrm{P}_{64}$ are populations for age groups $0-14,15-64$, and 65-99, respectively. $\Delta \mathrm{C}_{58}$ and $\Delta \mathrm{C}_{59}$ are both changes in $1 \mathrm{Max}$ of $\mathrm{NO}_{2}$, and $\Delta \mathrm{C}_{64}$ represents the change in 24Mean of $\mathrm{NO}_{2}$. To calculate the reduction in the medical expenses, the corresponding $\mathrm{VM}_{\mathrm{i}}$ is used in Equation (3).

For Kyoto, the medical records for each age group associated with air quality measurements that could replace the BenMAP analyses were not readily available. Hence, the parameters, $\mathrm{IM}_{\mathrm{i}}$ and $\mathrm{VMi}$, were modified for Kyoto based on the assumption that the response of humans to air pollution is the same, whether it is in the US or in Japan. In this process, the years for the maximum (baseline year) and minimum (control year) annual mean concentrations from 2010 to 2016 were first identified for each of the four air pollu- 
tants in Kyoto. All the US counties were then searched to identify those that had the closest concentration for baseline and control years as well as the change between the two years for each of the seven metrics for each air pollutant. A reference US county for each metric for each air pollutant was assigned to Kyoto through these processes. Adverse health incidence for each endpoint for each age group was adjusted based on the population ratio between Kyoto and the reference counties. Monetary values per incidence were adjusted based on the ratio (46\%) of the mean medical expenses between Japan and the US [36]. For WLD and SLD, the monetary value per incidence was adjusted based on the ratio (65\%) of the mean household income between Japan and the US [37]. For the monetary value for $\mathrm{M}$, the median value for a statistical life (VSL) derived from the literature in Japan [38] was employed.

\subsubsection{Heating and Cooling Energy Savings in Houses}

Based on McPherson and Simpson [9] and Nowak et al. [58], i-Tree Eco estimates changes in heating and cooling demands for houses with two or fewer floors based on shade, windbreak, and transpiration effects by trees with $6 \mathrm{~m}$ or taller and located within $18 \mathrm{~m}$ from the house and windbreak effects by other buildings.

In $\mathrm{i}$-Tree Eco, for 11 climate regions in the US, the base values of $\mathrm{CO}_{2}$ emission change because of changes in demands for cooling and heating due to tree shade and windbreak effects are stored in look-up tables for the combination of the three house vintages (pre1950/1950-80/post-1980), leaf type (deciduous/evergreen), tree height (6-10/10-15/15 m or taller), the distance between a tree and a house (0-6/6-12/12-18 $\mathrm{m})$, and eight directions from a house to a tree. In addition, the base $\mathrm{CO}_{2}$ emission changes because of changes in the heating and cooling demands affected by the transpiration from trees and the windbreak by buildings are stored in look-up tables for $10 \%, 30 \%$, and $60 \%$ of trees and building covers combined in each climate region.

It was ideal if this kind of base values of $\mathrm{CO}_{2}$ emission change due to tree effects were readily available in Kyoto, but it was not the case. Thus, based on the assumption that human's demand for cooling and heating is the same in the US and Japan, these look-up tables were used in this study by referencing a US climate region that best fits the climate in Kyoto. The approach requires four steps: (1) from 16 cities representing each US climate zone defined in McPherson [59], six candidate reference cities (RCs) were selected by comparing heating degree days (HDDs), cooling degree days (CDDs), and annual precipitation with the subject city (SC), Kyoto; (2) the root mean square error (RMSE) of climatic variables between the RCs and SC was calculated using Equation (4), where a, b, and $c$ are positive weighting coefficients that add to 1.0, expressing the relative importance of each variable, (3) one RC with the minimum RMSE was selected as the reference city for Kyoto, and (4) a climate region in which the selected RC falls into is selected from i-Tree Eco's 11 climate regions [9].

$$
R M S E=\sqrt{a\left(H D D_{S C}-H D D_{R C}\right)^{2}+b\left(C D D_{S C}-C_{D D}\right)^{2}+c\left(A P_{S C}-A P_{R C}\right)^{2}}
$$

In the US, the thermal resistance (R-value) for each part (wall, ceiling, window, floor, and foundation) of the default housing for each vintage for each climate region are defined [9], whereas, in Japan, the heat loss coefficient (Q-value) for an entire house is defined as an energy conservation standard [60]. By integrating housing parts with R-value into the entire house, the Q-value for the default house was calculated, which, in turn, was compared to the standard in Japan to identify the match of the house vintages between the US and Japan.

Building data for Kyoto was obtained from the Geospatial Information Authority of Japan [39]. Residential houses were identified with a footprint of $100 \mathrm{~m}^{2}$ or less, based on an average footprint of the area [61], and the direction and distance between the closest tree to each house were calculated using a geographical information system (GIS). Trees less than $6 \mathrm{~m}$ in height were excluded in this study because they are too low to affect the 
energy use in nearby houses. Houses located farther than $18 \mathrm{~m}$ from the nearest street tree were excluded as they were too far from the tree for their energy use to be affected.

\subsubsection{Avoided Stormwater Runoff}

i-Tree Eco estimates avoided stormwater runoff based on Hirabayashi [62], in which storm water runoff for two scenarios, (1) with the current tree cover and (2) with no tree cover in the study area, were calculated. The difference between the two scenarios was considered avoided stormwater runoff because of the existence of the trees. Within the model, hourly precipitation, rainfall intercepted by tree leaves determined based on LAI, evaporation from leaves, rainwater dropped to the ground, infiltration of the pervious cover, and runoff from the impervious cover were calculated based on Wang et al. [63]. One limitation here is that because the soil information is not available in i-Tree Eco, it was assumed that all the rainwater reaching the pervious cover infiltrates into the ground, while the rainwater reaching the impervious cover all runoffs. Average impervious and pervious covers for the study area were determined based on JAXA's ALOS-2 land cover data [49], and it was assumed that these values were uniform across the study area. The valuation for the avoided runoff was performed with the default value in i-Tree Eco, which is $2.36 \mathrm{US} \$ / \mathrm{m}^{3}$ for stormwater control facilities in the US.

\section{Results}

\subsection{Species Composition}

The 1230 street tree samples in our study included 27 species belonging to 19 genera from 18 families. The nine most widely planted species were G. biloba $(47.80 \%)$, A. buergerianum $(14.15 \%)$, Z. serrata $(8.13 \%)$, L. tulipifera $(6.18 \%)$, C. florida $(4.80 \%)$, P. $\times$ acerifolia $(4.15 \%)$, P. $\times$ yedoensis $(3.41 \%)$, P. jamasakura $(2.20 \%)$, and S. babylonica $(1.22 \%)$. G. biloba was the most dominant species, accounting for approximately half of the total population. The three most abundant tree species, which covered $67.91 \%$ of the total leaf area, were G. biloba $(33.50 \%)$, Z. serrata $(19.59 \%)$, and A. buergerianum $(14.82 \%)$, whereas Z. serrata $\left(255.67 \mathrm{~m}^{2} /\right.$ tree), $P . \times$ yedoensis $\left(174.17 \mathrm{~m}^{2} /\right.$ tree $)$, and $P . \times$ acerifolia $\left(159.36 \mathrm{~m}^{2} /\right.$ tree $)$ provided the most leaf area on a per tree basis (Table 2). 
Table 2. Predominant street tree species and their annual carbon storage and sequestration values in Kyoto City.

\begin{tabular}{|c|c|c|c|c|c|c|c|c|c|c|c|c|c|}
\hline \multirow{2}{*}{ Species } & \multirow{2}{*}{$\begin{array}{l}\text { Total Tree } \\
\text { Numbers }\end{array}$} & \multirow{2}{*}{$\begin{array}{c}\text { Avg. Tree } \\
\text { Height } \\
\text { (m) }\end{array}$} & \multirow{2}{*}{$\begin{array}{l}\text { Avg. } \\
\text { DBH } \\
\text { (cm) }\end{array}$} & \multicolumn{3}{|c|}{ Leaf Area $\left(m^{2}\right)$} & \multicolumn{3}{|c|}{ Carbon Storage (kg) } & \multicolumn{3}{|c|}{ Carbon Sequestered (kg/Year) } & \multirow{2}{*}{$\begin{array}{c}\text { Total } \\
\text { Value (\$) }\end{array}$} \\
\hline & & & & Avg. & Total & $\%$ of Total & Avg. & Total & Value (\$) & Avg. & Total & Value (\$) & \\
\hline G. biloba & 588 & 8.55 & 26.10 & 74.34 & $43,712.71$ & 33.50 & 156.64 & $92,107.67$ & $17,316.24$ & 13.08 & 7693.40 & 1446.35 & $18,762.59$ \\
\hline A. buergerianum & 174 & 8.76 & 29.21 & 111.12 & $19,335.92$ & 14.82 & 207.80 & $36,158.83$ & 6797.86 & 14.68 & 2554.77 & 480.27 & 7278.13 \\
\hline Z. serrata & 100 & 11.94 & 35.47 & 255.66 & $25,566.32$ & 19.59 & 435.42 & $43,542.36$ & 8185.96 & 17.95 & 1795.50 & 337.55 & 8523.51 \\
\hline L. tulipifera & 76 & 8.41 & 19.08 & 116.03 & 8818.77 & 6.76 & 77.82 & 5914.48 & 1111.92 & 7.37 & 560.32 & 105.34 & 1217.26 \\
\hline C. florida & 59 & 4.90 & 10.34 & 54.28 & 3203.04 & 2.45 & 18.81 & 1110.04 & 208.68 & 3.64 & 214.92 & 40.40 & 249.08 \\
\hline P. $\times$ acerifolia & 51 & 9.74 & 30.14 & 159.36 & 8127.75 & 6.23 & 200.55 & $10,228.19$ & 1922.90 & 14.88 & 759.13 & 142.71 & 2065.61 \\
\hline P. $\times$ yedoensis & 42 & 7.94 & 49.26 & 174.17 & 7315.23 & 5.64 & 1039.25 & $43,648.77$ & 8205.94 & 27.10 & 1138.38 & 214.01 & 8419.95 \\
\hline P. jamasakura & 27 & 6.30 & 20.59 & 110.66 & 2988.00 & 2.29 & 138.02 & 3726.60 & 700.69 & 8.49 & 229.41 & 43.12 & 743.81 \\
\hline S. babylonica & 15 & 8.91 & 34.08 & 109.38 & 1640.84 & 1.25 & 316.87 & 4753.12 & 893.58 & 15.27 & 229.15 & 43.07 & 936.65 \\
\hline Other species & 98 & & & & 9750.37 & 7.47 & & 3592.93 & 2508.84 & & 190.91 & 147.61 & 2656.45 \\
\hline Total & 1230 & & & & $130,458.95$ & 100.00 & & $244,782.99$ & $47,852.61$ & & $15,365.89$ & 3000.43 & $50,853.04$ \\
\hline
\end{tabular}




\subsection{Size Distribution}

The size distribution (in terms of diameter at breast height, DBH) is a key factor in managing a resilient tree population, influencing present and future costs as well as the flow of ecological benefits [64].

The DBH structure of street trees in Kyoto city was distributed unevenly comparing to the "ideal" size distribution proposed by [65], with a preponderance of maturing $(15-30 \mathrm{~cm}$ DBH), mature (30-45 cm DBH) street trees, which account for $43.90 \%$ and $33.30 \%$, respectively. The distribution indicated that many of Kyoto city's street trees were planted 20 to 50 years ago, and they provide maximum benefits because of their size and condition. There is a paucity of young, small-diameter classes $(0-15 \mathrm{~cm} \mathrm{DBH})$, where the proportion is $17.8 \%$ lower than the ideal for offset establishing-related mortality. The species most heavily represented in the large, mature classes $(>30 \mathrm{~cm} \mathrm{DBH})$ included Z. serrata $(66.70 \%)$, A. buergerianum $(49.50 \%), P . \times$ acerifolia $(51.00 \%)$, and S. babylonica $(76.30 \%)$. Notably, $P$. $\times$ yedoensis $(31.00 \%)$ was present in old tree classes $(>60 \mathrm{~cm} \mathrm{DBH})$, offering extensive ecological services in Kyoto city (Figure 2).

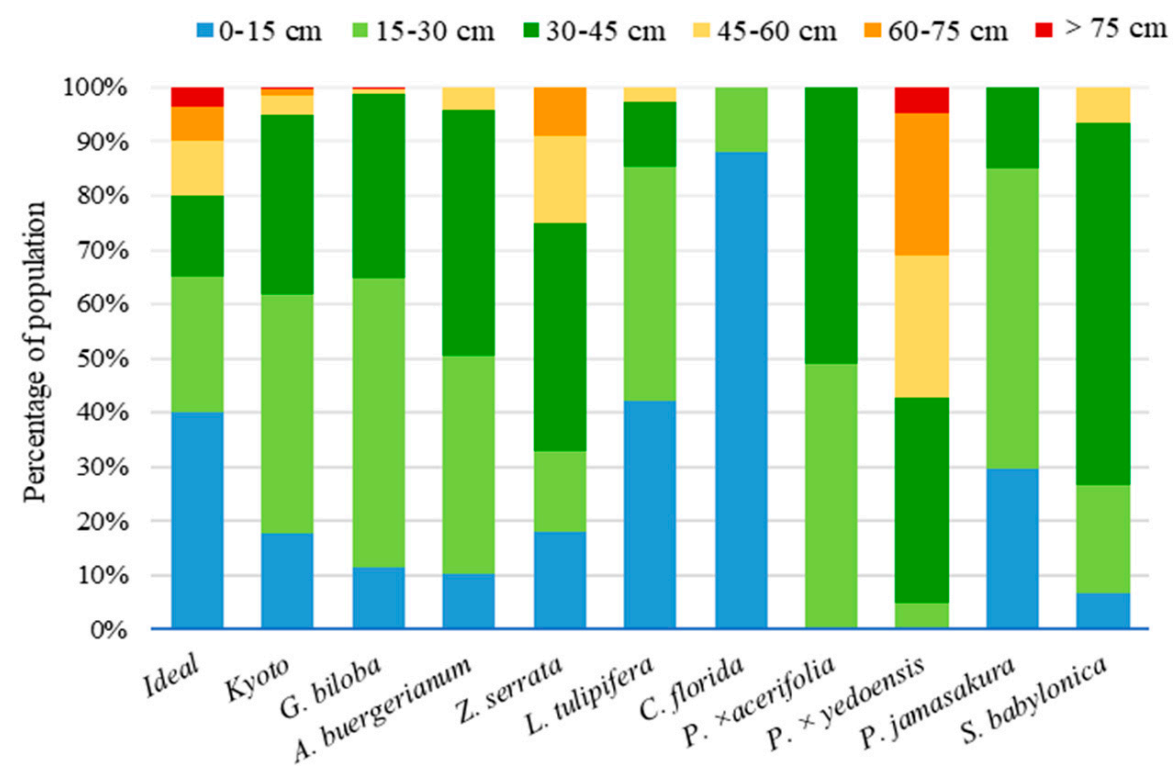

Figure 2. Diameter at breast height (DBH) size distribution of predominant street tree species compared to an "ideal" distribution [65]. Note: The "Kyoto" classification represents the total of the sampled street trees.

\subsection{Ecosystem Services}

\subsubsection{Carbon Storage and Sequestration}

Kyoto City's 1230 sample street trees were estimated to store $244.782 \mathrm{t}(\mathrm{US} \$ 47,852.61)$ in their biomass, and the gross sequestration per year was approximately $15.365 \mathrm{t}$ (US\$3000.43). G. biloba $(38.36 \%)$, Z. serrata $(17.42 \%)$, and P. $\times$ yedoensis $(17.21 \%)$ stored and sequestered the greatest amount of carbon due to their numbers and age. On a per tree basis, the carbon storage and sequestration benefits were US $\$ 41.34 /$ tree on average. $P . \times$ yedoensis produced the greatest net value at approximately US $\$ 200.47 /$ tree. Moreover, Z. serrata (US\$85.23/tree) and S. babylonica (US\$62.44/tree) also significantly contributed to offset carbon emissions. Conversely, C. florida (US\$4.22/tree), L. tulipifera (US\$16.01/tree), and $P$. jamasakura (US\$27.54/tree) were well below the average value (Table 2).

\subsubsection{Air Pollutant Removal \& Avoided Stormwater Runoff}

Air pollution removal was estimated at approximately $178.26 \mathrm{~kg}(30.82 \mathrm{~kg}$ for NO2, $121.79 \mathrm{~kg}$ for O3, $10.90 \mathrm{~kg}$ for PM2.5, and $14.75 \mathrm{~kg}$ for $\mathrm{SO}_{2}$ ) annually (Table 3). 
Table 3. Annual air quality and avoided rainwater runoff benefits from sample street trees in Kyoto City.

\begin{tabular}{|c|c|c|c|c|c|c|c|}
\hline \multirow{2}{*}{ Species } & \multirow{2}{*}{$\begin{array}{l}\text { Total Tree } \\
\text { Number }\end{array}$} & \multicolumn{4}{|c|}{ Annual Air Quality Effects } & \multicolumn{2}{|c|}{ Stormwater Runoff Reduction } \\
\hline & & $\begin{array}{c}\mathrm{NO}_{2} \text { Removal } \\
\text { (g) }\end{array}$ & $\mathrm{O}_{3}$ Removal (g) & $\begin{array}{c}\mathrm{PM}_{2.5} \\
\text { (g) }\end{array}$ & $\mathrm{SO}_{2}$ removal $(\mathrm{g})$ & $\begin{array}{l}\text { Avoided Runoff } \\
\left(\mathrm{m}^{3} / \text { Year }\right)\end{array}$ & Total Value (\$) \\
\hline G. biloba & 588 & 8963.73 & $38,190.11$ & 3604.32 & 4557.33 & 514.30 & 1214.10 \\
\hline A. buergerianum & 174 & 3965.02 & $16,893.05$ & 1594.34 & 2015.89 & 227.50 & 537.04 \\
\hline Z. serrata & 100 & 5242.63 & $22,336.31$ & 2108.06 & 2665.45 & 300.80 & 710.09 \\
\hline L. tulipifera & 76 & 1808.37 & 7704.62 & 727.15 & 919.41 & 103.75 & 244.93 \\
\hline C. florida & 59 & 656.81 & 2798.37 & 264.10 & 333.93 & 37.68 & 88.96 \\
\hline P. $\times$ acerifolia & 51 & 1666.67 & 7100.90 & 670.17 & 847.37 & 95.62 & 225.74 \\
\hline P. $\times$ yedoensis & 42 & 1500.01 & 6391.03 & 603.17 & 762.66 & 86.06 & 203.17 \\
\hline P. jamasakura & 27 & 612.72 & 2610.50 & 246.37 & 311.51 & 35.15 & 82.99 \\
\hline S. babylonica & 15 & 336.47 & 1433.54 & 135.29 & 171.06 & 19.30 & 45.57 \\
\hline Other species & 98 & 6068.47 & $16,338.24$ & 955.01 & 2167.68 & 279.23 & 659.17 \\
\hline Total & 1230 & $30,820.90$ & $121,796.67$ & $10,907.98$ & $14,752.29$ & 1699.39 & 4011.76 \\
\hline
\end{tabular}

Kyoto's sample street trees intercepted approximately $1699.39 \mathrm{~m}^{3}$ of rainfall annually, and this effect was associated with the benefits of stormwater runoff reduction at US $\$ 4011.76$ (Table 3). On average, each street tree contributed to an intercept of $1.38 \mathrm{~m}^{3}$ of rainfall annually and provided a value of US\$3.26. Z. serrata (US\$7.10/tree), P. $\times$ yedoensis (US $\$ 4.83 /$ tree), and $P . \times$ acerifolia (US $\$ 4.42 /$ tree) had the greatest effect on stormwater runoff reduction benefits.

\subsubsection{Human Health Effects}

Table 4 shows the information about US reference counties surveyed for BenMAP calculations. Based on air quality improvement, the avoided incidence of adverse health effects was estimated to be 3.8 cases and the associated economic value of US $\$ 14,515.05$ annually or US\$11.80/tree. The greatest amount of removal occurred with the $\mathrm{O}_{3}$ and $\mathrm{NO}_{2}$ pollutants, while the greatest value associated with removal was for $\mathrm{PM}_{2.5}$ and $\mathrm{O}_{3}$ (Table 5). Most of these monetary values were dominated by the effects of reducing human mortality because BenMAP assigns the greatest value per incidence for human mortality by averaging US\$3.9 million per incidence [66].

Table 4. Reference US counties for each metric and air pollutant assigned to Kyoto, Japan.

\begin{tabular}{|c|c|c|c|c|c|c|}
\hline \multirow{2}{*}{ Pollutant } & \multirow{2}{*}{ Metric } & \multicolumn{2}{|c|}{ Kyoto City } & \multicolumn{3}{|c|}{ Reference Counties } \\
\hline & & Baseline Value & Control Value & & Baseline Value & Control Value \\
\hline \multirow[t]{4}{*}{$\mathrm{NO}_{2}$} & 1Max & 32.56 & 26.69 & Ohio, Richland & 32.47 & 26.64 \\
\hline & 4Mean & 20.93 & 17.19 & Ohio, Wood & 20.80 & 17.25 \\
\hline & $8 \operatorname{Max}$ & 24.23 & 19.75 & $\begin{array}{l}\text { California, San } \\
\text { Francisco }\end{array}$ & 24.15 & 19.77 \\
\hline & 24Mean & 17.74 & 14.29 & $\begin{array}{l}\text { California, } \\
\text { Alameda }\end{array}$ & 17.81 & 14.46 \\
\hline \multirow[t]{4}{*}{$\mathrm{O}_{3}$} & $1 \mathrm{Max}$ & 53.95 & 45.37 & Illinois, Cook & 53.60 & 45.24 \\
\hline & 8Mean & 43.04 & 35.66 & $\begin{array}{l}\text { North Dakota, } \\
\text { Dunn }\end{array}$ & 43.17 & 36.05 \\
\hline & $8 \operatorname{Max}$ & 46.16 & 38.85 & $\begin{array}{l}\text { Vermont, } \\
\text { Franklin }\end{array}$ & 46.43 & 39.12 \\
\hline & 24Mean & 32.11 & 27.42 & $\begin{array}{l}\text { West Virginia, } \\
\text { Boone }\end{array}$ & 32.06 & 27.43 \\
\hline \multirow[t]{2}{*}{$\mathrm{PM}_{2.5}$} & 24Mean & 18.14 & 12.88 & Ohio, Athens & 18.19 & 13.10 \\
\hline & 24MeanQ & 18.15 & 12.88 & Ohio, Athens & 18.19 & 13.08 \\
\hline \multirow[t]{4}{*}{$\mathrm{SO}_{2}$} & $1 \mathrm{Max}$ & 6.22 & 4.46 & Iowa, Grundy & 6.22 & 4.60 \\
\hline & 3Mean & 4.60 & 3.27 & $\begin{array}{l}\text { Oklahoma, } \\
\text { Okfuskee }\end{array}$ & 4.59 & 3.27 \\
\hline & 8 Max & 5.20 & 3.86 & $\begin{array}{l}\text { Wisconsin, } \\
\text { Kewaunee }\end{array}$ & 5.21 & 3.88 \\
\hline & 24Mean & 4.25 & 3.31 & Idaho, Cassia & 4.15 & 3.22 \\
\hline
\end{tabular}


Table 5. Annual reduction in adverse health effect incidences and associated monetary value (\$) due to pollutant reduction from sample street trees in Kyoto City.

\begin{tabular}{|c|c|c|c|c|c|c|c|}
\hline \multirow{2}{*}{ Pollutant } & \multirow{2}{*}{ Adverse Health Effect } & \multicolumn{3}{|c|}{ Incidence (Case) } & \multicolumn{3}{|c|}{ Value (\$) } \\
\hline & & & Subtotal & Total & & Subtotal & Total \\
\hline \multirow{4}{*}{$\mathrm{NO}_{2}$} & Hospital Admissions, Respiratory & 0.004 & \multirow{4}{*}{0.696} & & 52.99 & \multirow{4}{*}{79.04} & \multirow{25}{*}{$14,515.05$} \\
\hline & Emergency Room Visits, Respiratory & 0.001 & & & 0.22 & & \\
\hline & Asthma Exacerbation & 0.650 & & & 25.23 & & \\
\hline & Acute Respiratory Symptoms & 0.041 & & & 0.60 & & \\
\hline \multirow{5}{*}{$\mathrm{O}_{3}$} & Acute Respiratory Symptoms & 1.335 & \multirow{5}{*}{1.624} & & 52.72 & \multirow{5}{*}{3191.59} & \\
\hline & Hospital Admissions, Respiratory & 0.003 & & & 37.37 & & \\
\hline & Mortality & 0.001 & & & 3083.29 & & \\
\hline & School Loss Days & 0.284 & & & 18.11 & & \\
\hline & Emergency Room Visits, Respiratory & 0.001 & & & 0.10 & & \\
\hline \multirow{12}{*}{$\mathrm{PM}_{2.5}$} & Acute Bronchitis & 0.001 & \multirow{12}{*}{1.394} & & 0.03 & & \\
\hline & Acute Myocardial Infarction & 0.001 & & & 29.99 & & \\
\hline & Acute Respiratory Symptoms & 0.834 & & 3.8 & 37.79 & & \\
\hline & Asthma Exacerbation & 0.390 & & & 14.65 & & \\
\hline & Chronic Bronchitis & 0.001 & & & 110.99 & & \\
\hline & Emergency Room Visits, Respiratory & 0.000 & & & 0.06 & 1123400 & \\
\hline & Hospital Admissions, Cardiovascular & 0.001 & & & 11.02 & $11,234.00$ & \\
\hline & Hospital Admissions, Respiratory & 0.001 & & & 11.01 & & \\
\hline & Lower Respiratory Symptoms & 0.010 & & & 0.24 & & \\
\hline & Mortality & 0.003 & & & 11005.19 & & \\
\hline & Upper Respiratory Symptoms & 0.008 & & & 0.18 & & \\
\hline & Work Loss Days & 0.144 & & & 12.85 & & \\
\hline \multirow{4}{*}{$\mathrm{SO}_{2}$} & Acute Respiratory Symptoms & 0.007 & \multirow{4}{*}{0.069} & & 0.10 & \multirow{4}{*}{10.42} & \\
\hline & Asthma Exacerbation & 0.061 & & & 2.23 & & \\
\hline & Emergency Room Visits, Respiratory & 0.000 & & & 0.08 & & \\
\hline & Hospital Admissions, Respiratory & 0.001 & & & 8.01 & & \\
\hline
\end{tabular}

\subsubsection{Heating and Cooling Cost Reduction in Houses}

US Reference Climate Region for Kyoto

The best match city for Kyoto was Charleston, SC (RMSE $=1.47)$. Thus, the "US Southeast climate region" was used to model the environmental conditions in Kyoto using i-Tree Eco.

\section{House Vintage Adjustment}

Table 6 summarizes the R-value to Q-value conversion using Post-1980 vintage houses in the southeast climate region as an example. The inverse of the R-value is the heat transfer coefficient, U-value. The U-value is then multiplied by the area of interest including walls, ceilings, windows, floors, and foundations to obtain the heat loss value. The sum of the heat loss is divided by the floor area to obtain the Q-value, which is 2.45 .

Table 6. R-value and Q-value conversion results (post-1980 vintage for the southeast region).

\begin{tabular}{cccccc}
\hline & R-Value $\left(\mathbf{m}^{\mathbf{2}} \mathbf{K} / \mathbf{W}\right)$ & U-Value $\left(\mathbf{W} / \mathbf{m}^{\mathbf{2}} \mathbf{K}\right)$ & Area $\left(\mathbf{m}^{\mathbf{2}}\right)$ & Heat Loss $(\mathbf{W} / \mathbf{K})$ & $\mathbf{Q}-$ Value $\left(\mathbf{W} / \mathbf{m}^{\mathbf{2}} \mathbf{K}\right)$ \\
\hline Wall & 1.94 & 0.52 & 653.7 & 337.4 & \\
Ceiling & 4.75 & 0.21 & 205.5 & 43.2 & \\
Window & 0.40 & 2.50 & 24.5 & 61.3 & \\
Floor & 3.35 & 0.30 & 205.5 & 61.4 & \\
Found & 0.00 & 0.00 & 0.0 & 0.0 & \\
\hline
\end{tabular}

R-values for pre-1950 and 1950-1980 were also calculated with the above-described procedure. Table 7 summarizes the energy conservation standards in the US and Japan. The Q-value for post-1996 construction in Japan was 2.7, which is equivalent to that of the post1980 in the southeast climate region. Therefore, post-1996 houses in Japan were treated as post-1980 houses in the US. Higher Q-values indicate lower insulation capacity. The 
highest Q-value of 3.79 for Pre-1950 in the US corresponded with pre-1980 and 1981-1995 constructions in Japan.

Table 7. Japanese house vintages assignment to the US's vintages.

\begin{tabular}{|c|c|c|c|c|c|}
\hline \multicolumn{2}{|c|}{ US } & \multicolumn{2}{|c|}{ Japan } & \multirow{2}{*}{ Count ${ }^{a}$} & \multirow{2}{*}{ Ratio $^{b}$} \\
\hline House Vintage & Q-value $\left(W / m^{2} \mathrm{~K}\right)$ & House Vintage & Q-value $\left(W / m^{2} \mathrm{~K}\right)$ & & \\
\hline Pre-1950 & 3.79 & Pre-1980 & 5.2 & 178,280 & $40.0 \%$ \\
\hline Pre-1950 & 3.79 & 1981-1995 & 4.2 & 116,290 & $26.1 \%$ \\
\hline Post-1980 & 2.45 & Post-1996 & 2.7 & 151,390 & $33.9 \%$ \\
\hline
\end{tabular}

a: The number of houses that match the house vintage in this study of Kyoto city. ${ }^{\mathrm{b}}$ : The ratio of house that matches the house vintage in this study of Kyoto city.

\section{Energy Saving}

Among the 1230 sampled street trees, 614 trees affected the energy consumption of 1 or 2-story houses by shading buildings, providing evaporative cooling, and blocking winter winds. The annual energy-related costs were estimated at US\$2054.36 using customized parameters (Table 8).

\subsubsection{Annual Net Benefits and Costs}

Annual Benefits

The total annual value of sample street trees was evaluated by summing the four different estimated ES benefits, which were calculated at US $\$ 71,434.21$ annually or US $\$ 58.07$ per tree on average (Table 9). The largest benefits were carbon storage and sequestration, which accounted for $71.19 \%$ of the total benefits. In contrast, energy savings contributed the least to ES, at only $2.88 \%$ of the total benefits (Table 9). On a per tree basis, $P . \times$ yedoensis (US\$225.32/tree), Z. serrata (US\$123.21/tree), S. babylonica (US\$80.10/tree), and $P$. $\times$ acerifolia (US\$65.88/tree) produced significant benefits, whereas C. florida (US $\$ 11.78 /$ tree), L. tulipifera (US\$33.64/tree), P. jamasakura (US\$43.31/tree), and G. biloba (US\$43.74/tree) produced the least benefits (Table 10). 
Table 8. Annual energy savings and monetary values provided by street trees in Kyoto City.

\begin{tabular}{|c|c|c|c|c|c|c|c|c|c|}
\hline Leaf Type & Direction & Mean Distance (m) & Tree Count & Mean DBH (cm) & Mean Leaf Area $\left(\mathrm{m}^{2}\right)$ & Mean Height (m) & Electricity (\$) & Fuel (\$) & Total (\$) \\
\hline Deciduous & $\mathrm{N}$ & 8.6 & 81 & 26.68 & 92.29 & 8.53 & 211.61 & 100.10 & 311.71 \\
\hline Deciduous & NE & 7.5 & 56 & 28.22 & 93.54 & 8.63 & 132.57 & 58.01 & 190.58 \\
\hline Deciduous & $\mathrm{E}$ & 7.8 & 99 & 29.02 & 109.82 & 9.11 & 749.00 & -168.32 & 580.67 \\
\hline Deciduous & $\mathrm{SE}$ & 6.4 & 67 & 30.77 & 120.35 & 9.17 & 91.56 & -202.98 & -111.42 \\
\hline Deciduous & $\mathrm{S}$ & 7.2 & 80 & 26.49 & 102.44 & 8.52 & 25.54 & -525.78 & -500.23 \\
\hline Deciduous & SW & 9.2 & 55 & 29.10 & 112.25 & 9.01 & 47.58 & -268.79 & -221.20 \\
\hline Deciduous & W & 7.6 & 102 & 27.58 & 111.99 & 8.82 & 1911.60 & -524.61 & 1386.98 \\
\hline Deciduous & NW & 7.8 & 64 & 28.84 & 110.72 & 8.85 & 278.53 & 64.52 & 343.05 \\
\hline Evergreen & $\mathrm{NE}$ & 15.6 & 1 & 33.00 & 101.92 & 6.50 & 3.72 & 3.24 & 6.97 \\
\hline Evergreen & $\mathrm{E}$ & 2.0 & 1 & 22.00 & 47.69 & 6.40 & 3.78 & -1.02 & 2.76 \\
\hline Evergreen & $\mathrm{s}$ & 8.6 & 2 & 36.25 & 212.94 & 7.70 & 0.01 & -4.70 & -4.69 \\
\hline Evergreen & SW & 9.8 & 1 & 23.50 & 121.23 & 8.80 & 1.44 & -0.54 & 0.89 \\
\hline Evergreen & W & 12.5 & 5 & 29.96 & 72.08 & 8.00 & 63.65 & 4.63 & 68.29 \\
\hline Total & & & 614 & & & & 3520.59 & -1466.24 & 2054.36 \\
\hline
\end{tabular}

Note: negative numbers indicate that there was no reduction in carbon emissions and/or value, and instead, carbon emission and values increased by the amount reported as negative. 
Table 9. Annual benefits-cost summary of sample street trees.

\begin{tabular}{cccc}
\hline & Monetary Value (\$) & \% of Total Benefits & Value (\$)/Tree \\
\hline $\begin{array}{c}\text { Benefits } \\
\text { Carbon storage \& }\end{array}$ & $50,853.04$ & & \\
sequestration (C) & 4011.76 & 71.19 & 41.34 \\
$\begin{array}{c}\text { Stormwater runoff } \\
\text { reduction (S) }\end{array}$ & $14,515.05$ & 5.62 & 3.26 \\
$\begin{array}{c}\text { Adverse health } \\
\text { mitigation (A) }\end{array}$ & 2054.36 & 20.32 & 11.80 \\
Energy saving (E) & $71,434.21$ & 2.88 & 1.67 \\
Total (C+S+A+E) & & 100.00 & 58.07 \\
\hline Tree management & & & 90.00 \\
cost & & & \\
\hline
\end{tabular}

Table 10. Monetary value of predominant street tree species in Kyoto City.

\begin{tabular}{|c|c|c|c|c|c|}
\hline Species & Total Tree Numbers & Avg. Tree Height (m) & Avg. DBH (cm) & Avg. Leaf Area(m $\left.{ }^{2}\right)$ & $\$ /$ Tree \\
\hline G. biloba & 588 & 8.55 & 26.10 & 74.34 & 43.74 \\
\hline A. buergerianum & 174 & 8.76 & 29.21 & 111.12 & 58.73 \\
\hline Z. serrata & 100 & 11.94 & 35.47 & 255.66 & 123.21 \\
\hline L. tulipifera & 76 & 8.41 & 19.08 & 116.03 & 33.64 \\
\hline C. florida & 59 & 4.90 & 10.34 & 54.28 & 11.78 \\
\hline P. $\times$ acerifolia & 51 & 9.74 & 30.14 & 159.36 & 65.88 \\
\hline P. $\times$ yedoensis & 42 & 7.94 & 49.26 & 174.17 & 225.32 \\
\hline P. jamasakura & 27 & 6.30 & 20.59 & 110.66 & 43.31 \\
\hline S. babylonica & 15 & 8.91 & 34.08 & 109.38 & 80.10 \\
\hline
\end{tabular}

\section{Expenditures}

Based on the information provided by the Green Policy Promotion Office of the Kyoto City Construction Bureau, the municipality of Kyoto spent exceed US $\$ 4,500,000$ to maintain the population of 50,000 street trees annually including the costs of pruning, cleaning the fallen leaves, and pest and disease control. The average annual street tree expenditure is estimated at US\$90 $(90=4,500,000 / 50,000)$ (Kyoto City Construction Bureau, personal communication). Results are reported in US dollars, economic data collected in Japanese Yen were converted to US dollars using an exchange rate of 1US dollar to 110 Yen (Table 9).

\section{Discussion}

This study in Kyoto is the first attempt to use the empirical data in quantifying the ES of street trees, and the results could provide the municipality with baseline values for future management.

Our results indicate that large-growing species with more leaf area, such as $P . \times$ yedoensis (174.17 $\mathrm{m}^{2} /$ tree, US\$225.32/tree), Z. serrata $\left(255.66 \mathrm{~m}^{2} /\right.$ tree, US\$123.21/tree), and $P . \times$ acerifolia $\left(159.36 \mathrm{~m}^{2} /\right.$ tree, US $\$ 65.88 /$ tree $)$ appeared to be the most valuable species in Kyoto city, which reflects the importance of the leaf area is the driving force behind the ability of trees to offer ecological benefits for the community. Many previous studies have pointed out that tree canopy cover and leaf area play a key role in determining the delivery of ES $[5,19,66]$. The greater the tree canopy size, the greater the pollution removal and precipitation intercept, and the greater the value provided $[5,21,22,66]$. Maintaining the health and longevity of these large trees is critical to achieving high ES levels in Kyoto city.

\subsection{Benefits-Cost Comparison}

Regarding the benefits-cost ratio, it was demonstrated that the value of the annual benefits generated by street trees in Kyoto city did not outweigh tree-related expenditure. This finding could be explained by three factors: first, the most dominant species, G. biloba 
(US\$43.74/tree), which accounted for $47.8 \%$ of the entire population, also had a low tree canopy cover and therefore provided a low level of benefit. In Kyoto city, the average leaf area of G. biloba $\left(74.34 \mathrm{~m}^{2} /\right.$ tree $)(\mathrm{DBH}=26.1 \mathrm{~cm}$, height $=8.55 \mathrm{~m})$ is considerably lower than that of the same species in other cities. Peper et al. [67] predicted the size of 12 common street trees growing in Modesto, CA, USA, and showed that the leaf area of G. biloba was $235.29 \mathrm{~m}^{2} /$ tree $(\mathrm{DBH}=38.7 \mathrm{~cm}$, height $=11.74 \mathrm{~m})$. The difference may be primarily due to the street tree management practices implemented in Kyoto city. The conflict between street tree expansion and constrained planting space is prominent in Japan, resulting heavy pruning, which suppresses the growth of tree canopy [68].

Additionally, on a per-tree basis, expenditure for street trees in Kyoto city (US\$90) is the highest compared with cities in the US and Europe, such as New York City, US (US\$37), Santa Monica, US (US\$53), Lisbon, Portugal (US\$46) [21,69,70]. Considering the need for frequent pruning, the likelihood of increases in the burden of municipal expenditure is very high in Japan [68].

Furthermore, the estimation of the benefits presented in this study represents only a fraction of the comprehensive value of Kyoto's street trees. In light of the experience from other case studies conducted with the i-Tree Street model, property value accounted for the most important benefits in all cities [70]. Trees contribute many "other" intangible benefits that are difficult to translate into economic terms, such as biodiversity, beautification, increased human comfort, and sense of place, which cannot yet be factored into the i-Tree Eco model. Kyoto City is a world-famous tourist destination, and street trees in the City are considered a significant attraction for tourists as well as a benefit for urban residents. In recent years, various levels of government in Kyoto have become increasingly aware of the importance of street trees and have made a renewed investment in the median strip planting project. Additional research is needed in this area to provide reliable information on factors such as property attributes, market responses, and willingness to pay.

\subsection{Advantages}

i-Tree Eco is composed of three elements: model codes, model parameters, and input data. One advantage of $\mathrm{i}$-Tree Eco is that it uses model parameters and input data globally applicable or flexibly substitutable to local site-specific values when running it in the region outside the US [51]. Those parameters/data globally applicable are denoted with " $a$ " in Table 1, including the social cost of carbon and worldwide weather and upper air data stored in i-Tree server computers. Model parameters/input data that an international user can replace via ITDB are location-related data, precipitation, air quality, and energy prices (denoted with " $\mathrm{b}$ " in Table 1).

In addition, with the cooperation of an i-Tree developer, the model codes and parameters (denoted with " $c$ " in Table 1) were modified in this study. As a result, it has become possible to estimate the air pollution removal and the avoided stormwater runoff by employing solar and net radiations measured in the vicinity of Kyoto rather than estimated values employed in i-Tree Eco.

Regarding the health effects, the analysis available through ITDB for typical international users is very limited. A regression equation for each of the four air pollutants $(\mathrm{CO}$, $\mathrm{NO}_{2}, \mathrm{O}_{3}$, and $\mathrm{PM}_{2.5}$ ) relating population density and monetary values avoided due to air quality improvement was constructed based on the county-based i-Tree Eco runs across the continental US [66]. What typical international i-Tree Eco users can do is to plug their population density into these regression equations to estimate the monetary values. It is impossible for them to calculate the avoided incidence and monetary values for each of the adverse health endpoints. By contrast, our study enabled us to quantify these detailed amounts by referencing counties in the US and adjusting their parameters for Kyoto.

Look-up tables utilized in i-Tree Eco to estimate the tree's effects on heating and cooling energy savings at houses across the US were developed based on lots of data collections, modeling, and analyses. These efforts were made possible thanks to funding and collaborations from national laboratories, federal agencies, non-profit organizations, 
local governments, and utility companies [9]. They also provided instruction on how to determine a reference US climate region for international applications of the method [59], and we followed it. Additionally, we developed a method to replace the US house vintages with those in Japan based on the energy conservation standards in the two countries. This is beyond what common international users can do using ITDB. The method we used in the study may be the best for now when using the look-up tables contained in i-Tree Eco.

\subsection{Limitations and Future Directions}

Despite the advantages brought by customizing i-Tree Eco's model codes, parameters, and input data, there still exists several limitations and uncertainties in the assumptions and processes conducted in this study, which in turn affect the validity of the results.

The modeled carbon values are estimates based on tree growth allometric equations from the US, and the carbon estimate error includes the uncertainty of using biomass equations and conversion factors [51]. It is well known that the growth characteristics of street trees are greatly affected by different management practices and climate conditions. An estimation uncertainty was present in the international case study using surrogate US species data. Currently, there are limited studies that have compiled growth equations for street trees in Japan [71]. Future research is needed to develop growth curves to understand the biomass equations for urban trees in Kyoto city with greater accuracy.

With regards to the health effects assessed, adverse health incidences and associated monetary values reduced because of the air quality improvement were estimated based on BenMAP, assuming that the response of humans to air pollution is the same in Japan and in the US. Although the process taken in this study to adjust the health effects in the reference US counties for Kyoto may be plausible when the established methods like BenMAP lack in Japan, there exist uncertainties in the assumption. For instance, susceptibility to air pollution may be affected by many factors such as genetic background, race, ethnicity, and culture [72] to name a few, which vary between Japan and the US. One future research direction is to explore epidemiologic data and develop methods in Japan that enable analyses like BenMAP.

In the process of the heating and cooling energy saving calculations, the matching of the climate region and the house vintages between Japan and the US were not perfect. Hence, uncertainties exist there. It is desirable to develop a similar means to quantify the trees' effects on household energy savings based on the climate and house characteristics in Japan.

Lin et al. [73] performed thorough sensitivity analyses on several components of i-Tree Eco (i.e., carbon storage/sequestration, bio-emissions, and dry deposition of air pollution) to identify important input variables for each analysis. It is suggested that increasing the accuracy of these important variables is an effective way to reduce uncertainty in the model output. Unfortunately, energy savings, health effects, and stormwater reductions that we assessed in this study were not included in these analyses. Therefore, it will be a great addition to the i-Tree research and user communities if the sensitivity analyses on these three components are performed in the future.

\section{Conclusions}

This study describes the first sample tree inventory data-based street tree ES assessment in Kyoto, Japan, by customizing the model and parameters of the i-Tree Eco model. The results presented in this study should be considered first-order estimations of the ES, since they were unable to validate against the ground truth due to a lack of such data. Despite that, treating our results as a reference value, they contribute new knowledge on the structure, function, and value of Kyoto's street trees.

For Kyoto City, the annual benefits produced by street trees were estimated at US58.1\$/tree. The trees that were estimated to contribute the most to ecosystem services were $P . \times$ yedoensis (US\$225.32/tree), Z. serrata (US\$123.21/tree), S. babylonica (US\$80.10/tree), and $P . \times$ acerifolia (US\$65.88/tree). 
Street tree survival, growth, and management in Kyoto city pose a unique set of problems because the majority of street trees are growing in a stressful urban environment that has been impacted and constrained by construction for many years. To maintain the flow of benefits the city currently enjoys, management recommendations derived from this analysis are as follows:

Continue investing in intensive maintenance of large-stature mature trees to prolong the lifespans of tree species such as $P . \times$ yedoensis, Z. serrata, and $P . \times$ acerifolia.

To maximize the trees' potential for reducing energy consumption and ensure longterm net benefits from continuous levels of tree canopy cover, heavy pruning should be discontinued, and planting strips should be advocated in new street tree plans.

It is recommended that diversification be continued to reduce dependence on species such as G. biloba, while concentrating on selecting tree species that can tolerate restricted site conditions, avoiding unnecessary pruning and management costs.

Author Contributions: X.T. conceived and designed the study, participated in sample collection, and wrote the original manuscript; S.H. performed model customizations and runs, contributed to the Materials and Methods and Discussion sections and revised the manuscript; S.S. was involved in project administration, revision, and editing. All authors have read and agreed to the published version of the manuscript.

Funding: This work was supported by JSPS KAKENHI grant number 18H02226.

Institutional Review Board Statement: Not applicable.

Informed Consent Statement: Not applicable.

Data Availability Statement: The data presented in this study are available on request from the corresponding author. The data are not publicly available due to privacy.

Acknowledgments: We thank the Kyoto City Construction Bureau for providing the park and street tree map.

Conflicts of Interest: The authors declare no conflict of interest.

\section{References}

1. Roy, S.; Byrne, J.; Pickering, C. A systematic quantitative review of urban tree benefits, costs, and assessment methods across cities in different climatic zones. Urban For. Urban Green 2012, 11, 351-363. [CrossRef]

2. Li, H.; Peng, J.; Yanxu, L.; Yi'na, H. Urbanization impact on landscape patterns in Beijing City, China: A spatial heterogeneity perspective. Ecol. Indic. 2017, 82, 50-60. [CrossRef]

3. Millennium Ecosystem Assessment (MEA). Ecosystems and Human Well-Being: Synthesis; Island Press: Washington, DC, USA, 2005.

4. TEEB Foundations. The Economics of Ecosystems and Biodiversity: Ecological and Economic Foundations; Earthscan: London, UK; Washington, DC, USA, 2010.

5. Lin, J.; Kroll, C.N.; Nowak, D.J.; Greenfield, E.J. A review of urban forest modeling: Implications for management and future research. Urban For. Urban Green 2019, 43, 126366. [CrossRef]

6. Raum, S.; Hand, K.; Hall, C.; Edwards, D.; O'Brien, L.; Doick, K. Achieving impact from ecosystem assessment and valuation of urban greenspace: The case of i-Tree Eco in Great Britain. Landsc. Urban Plan. 2019, 190, 103590. [CrossRef]

7. Daily, G.C. Introduction: What are Ecosystem Services; Island Press: Washington, DC, USA, 1997.

8. Dover, J.W. Green Infrastructure: Incorporating Plants and Enhancing Biodiversity in Buildings and Urban Environments; Routledge: Abingdon, UK; New York, NY, USA, 2015; pp. 220-227.

9. McPherson, E.G.; Simpson, J.R. Carbon Dioxide Reduction Through Urban Forestry; US Department of Agriculture, Forest Service, Pacific Southwest Research Station: Albany, CA, USA, 1999.

10. Nowak, D.J.; Crane, D.E. Carbon storage and sequestration by urban trees in the USA. Environ. Pollut. 2002, 116, 381-389. [CrossRef]

11. Nowak, D.J.; Crane, D.E.; Stevens, J.C. Air pollution removal by urban trees and shrubs in the United States. Urban For. Urban Green 2006, 4, 115-123. [CrossRef]

12. Jim, C.Y.; Chen, W.Y. Recreation-amenity use and contingent valuation of urban greenspaces in Guangzhou, China. Landsc. Urban Plan. 2006, 75, 81-96. [CrossRef]

13. Rahman, M.A.; Moser, A.; Rötzer, T.; Pauleit, S. Microclimatic differences and their influence on transpirational cooling of Tilia cordata in two contrasting street canyons in Munich, Germany. Agric. For. Meteorol. 2017, 232, 443-456. [CrossRef]

14. Rahman, M.A.; Stratopoulos, L.M.; Moser-Reischl, A.; Zölch, T.; Häberle, K.H.; Rötzer, T.; Pauleit, S. Traits of trees for cooling urban heat islands: A meta-analysis. Build Environ. 2020, 170, 106606. [CrossRef] 
15. Rahman, M.A.; Hartmann, C.; Moser-Reischl, A.; von Strachwitz, M.F.; Paeth, H.; Pretzsch, H.; Rötzer, T. Tree cooling effects and human thermal comfort under contrasting species and sites. Agric. For. Meteorol. 2020, 287, 107947. [CrossRef]

16. Livesley, S.J.; Baudinette, B.; Glover, D. Rainfall interception and stem flow by eucalypt street trees-The impacts of canopy density and bark type. Urban For. Urban Green 2014, 13, 192-197. [CrossRef]

17. Rahman, M.A.; Moser, A.; Anderson, M.; Zhang, C.; Rötzer, T.; Pauleit, S. Comparing the infiltration potentials of soils beneath the canopies of two contrasting urban tree species. Urban For. Urban Green 2019, 38, 22-32. [CrossRef]

18. Mullaney, J.; Lucke, T.; Trueman, S.J. A review of benefits and challenges in growing street trees in paved urban environments. Landsc. Urban Plan. 2015, 134, 157-166. [CrossRef]

19. Rogers, K.; Sacre, K.; Goodenough, J.; Doick, K. Valuing London's Urban Forest: Results of the London i-Tree eco Project; Treeconomics: London, UK, 2015.

20. Rötzer, T.; Moser-Reischl, A.; Rahman, M.A.; Grote, R.; Pauleit, S.; Pretzsch, H. Modelling Urban Tree Growth and Ecosystem Services: Review and Perspectives. In Progress in Botany; Springer: Cham, Switzerland, 2020; pp. 1-60.

21. Peper, P.J.; McPherson, E.G.; Simpson, J.R.; Gardner, S.L.; Vargas, K.E.; Xiao, Q.; Watt, F. New York City, New York Municipal Forest Resource Analysis; Center for Urban Forest Research, USDA Forest Service, Pacific Southwest Research Station: Davis, CA, USA, 2007.

22. Peper, P.J.; McPherson, E.G.; Simpson, J.R.; Vargas, K.E.; Xiao, Q.; Purcell, L.; Forester, I.C. City of Indianapolis, Indiana, Municipal Forest Resource Analysis; Center for Urban Forest Research. US Department of Agriculture, Pacific Southwest Research Station, Tech. Rep. for Indy Parks and Recreation Department: Indianapolis, IN, USA, 2008.

23. Jim, C.Y.; Chen, W.Y. Ecosystem services and valuation of urban forests in China. Cities 2009, 26, 187-194. [CrossRef]

24. Hirabayashi, S.; Tokue, Y.; Ito, A.; Ellis, A.; Hoehn, R.; Imamura, F.; Morioka, C. Estimating ecosystem services and their monetary values provided by street trees in Kawasaki ward of Kawasaki city using i-Tree Eco. J. Jpn. Soc. Reveg. Technol. 2016, 42, 4-49. [CrossRef]

25. Hirabayashi, S.; Tan, X.; Shibata, S. Customization of i-Tree Eco's energy saving and health effect models for Japan. J. Jpn. Soc. Reveg. Technol. 2019, 45, 200-203. (In Japanese)

26. Japan Meteorological Agency. Normal Value (Value for Each Year/Month) of Meteorological Data. Available online: https:/ /www. data.jma.go.jp /obd/stats/etrn/view / annually_s.php?prec_no=61\&block_no=47759\&year $=\&$ month $=\&$ day $=\& v i e w=($ accessed on 30 September 2020). (In Japanese)

27. Kyoto City Official Website. The Basic Plan for Green of Kyoto City. Available online: https://www.city.kyoto.lg.jp/kensetu/ page/0000077122.html (accessed on 30 September 2020). (In Japanese)

28. Ministry of Internal Affairs and Communications. Statistics of Japan. Available online: https://www.e-stat.go.jp/en/regionalstatistics/ssdsview/municipality (accessed on 30 September 2020).

29. US Forest Service. i-Tree Eco User's Manual v6.0. 2020. Available online: https://www.itreetools.org/documents/275/EcoV6 _UsersManual..2020.07.15.pdf (accessed on 23 February 2021).

30. Interagency Working Group on Social Cost of Greenhouse Gases, United States Government. Technical Support Document: Technical Update of the Social Cost of Carbon for Regulatory Impact Analysis under Executive Order 12866. 2016. Available online: https:/ / www.epa.gov/sites / production/files/2016-12/documents /sc_co2_tsd_august_2016.pdf (accessed on 30 September 2020).

31. Japan Meteorological Agency (JMA). 2018. Available online: https://www.data.jma.go.jp/obd/stats/etrn/index.php (accessed on 30 September 2020).

32. National Centers for Environmental Information (NCEI). Climate Data Online. 2019. Available online: https://www.ncdc.noaa. gov/cdo-web/ (accessed on 30 September 2020).

33. Earth System Research Laboratory. NOAA/ESRL Radiosonde Database. 2019. Available online: https://ruc.noaa.gov/raobs/ (accessed on 30 September 2020).

34. National Institute for Environmental Studies (NIES). Environmental Value Database. 2019. Available online: http:/ /www.nies.go. jp/igreen/ (accessed on 30 September 2020).

35. Kyoto City. Population for Kyoto City. 2018. Available online: https://www2.city.kyoto.lg.jp/sogo/toukei/Population/index. html (accessed on 30 September 2020).

36. OECD Data. "Health Spending". 2019. Available online: https://data.oecd.org/healthres/health-spending.htm (accessed on 30 September 2020).

37. OECD Data. Better Life Index. 2019. Available online: http://www.oecdbetterlifeindex.org/topics/income/ (accessed on 30 September 2020).

38. Miyazato, S. An estimation of value of a statistical life based on labor market data. Jpn. Econ. Res. 2010, 63, 1-28.

39. Geospatial Information Authority of Japan (GSI). 2018. Available online: http://www.gsi.go.jp/kiban (accessed on 30 September 2020).

40. Kyoto Prefecture Web Site. Available online: http://www.pref.kyoto.jp/tokei/yearly/tokeisyo/ts2015/tokeisyo2015a0618.xls (accessed on 30 September 2020).

41. Ministry of Environment (MoE). Available online: https://www.env.go.jp/press/files/jp/107786.pdf (accessed on 30 September 2020). 
42. Daigas Group. 2019. Available online: http://www.osakagas.co.jp/company/efforts / eco/co2/evaluation.html (accessed on 30 September 2020).

43. Ministry of Environment (MoE). Available online: https://www.env.go.jp/council/16pol-ear/y164-04/mat04.pdf (accessed on 30 September 2020).

44. Japan LP Gas Association. Available online: http://www.j-lpgas.gr.jp/nenten/co2.html (accessed on 30 September 2020).

45. Kansai Electric Power Company (KEPCO). Available online: https://kepco.jp/ryokin/menu/dento_a (accessed on 30 September 2020).

46. Daigas Group. 2019. Available online: http://home.osakagas.co.jp/price/menu/general_rate/index.html (accessed on 30 September 2020).

47. Agency for Natural Resources and Energy. Available online: https://www.enecho.meti.go.jp/statistics/petroleum_and_lpgas / pl007/results.html (accessed on 30 September 2020).

48. Oil Information Center. Available online: http:/ / oil-info.ieej.or.jp/price/price_ippan_lp_maitsuki.html (accessed on 30 September 2020).

49. Japan Aerospace Exploration Agency (JAXA). Available online: https://www.eorc.jaxa.jp/ALOS/lulc/lulc_jindex_v1803.htm (accessed on 30 September 2020).

50. Vargas, K.E.; McPherson, E.G.; Simpson, J.R.; Peper, P.J.; Gardner, S.L.; Xiao, Q. Temperate interior west community tree guide: Benefits, costs, and strategic planting. In General Technical Report; PSW-GTR-206; U.S. Department of Agriculture, Forest Service, Pacific Southwest Research Station: Albany, CA, USA, 2007; Volume 108.

51. Nowak, D.J.; Crane, D.E.; Stevens, J.C.; Hoehn, R.E.; Walton, J.T.; Bond, J. A ground-based method of assessing urban forest structure and ecosystem services. Arboric. Urban For. 2008, 34, 347-358.

52. Nowak, D.J.; Greenfield, E.J.; Hoehn, R.E.; Lapoint, E. Carbon storage and sequestration by trees in urban and community areas of the United States. Environ. Pollut. 2013, 178, 229-236. [CrossRef]

53. Hirabayashi, S.; Kroll, C.N.; Nowak, D.J. Component-based development and sensitivity analyses of an air pollutant dry deposition model. Environ. Modell. Softw. 2011, 26, 804-816. [CrossRef]

54. Hirabayashi, S.; Kroll, C.N.; Nowak, D.J. i-Tree Eco Dry Deposition Model Descriptions. 2015. Available online: http://www. itreetools.org/eco/resources/iTree_Eco_Dry_Deposition_Model_Descriptions.pdf (accessed on 23 February 2021).

55. Nowak, D.J.; Hirabayashi, S.; Bodine, A.; Hoehn, R. Modeled PM2. 5 removal by trees in ten US cities and associated health effects. Environ. Pollut. 2013, 178, 395-402. [CrossRef]

56. Hirabayashi, S.; Nowak, D.J. Comprehensive national database of tree effects on air quality and human health in the United States. Environ. Pollut. 2016, 215, 48-57. [CrossRef]

57. United States Environmental Protection Agency. Environmental Benefits Mapping and Analysis Program-Community Edition (BenMAP-CE). 2020. Available online: https:/ / www.epa.gov / benmap (accessed on 23 February 2021).

58. Nowak, D.J.; Appleton, N.; Ellis, A.; Greenfield, E. Residential building energy conservation and avoided power plant emissions by urban and community trees in the United States. Urban For. Urban Gree. 2017, 21, 158-165. [CrossRef]

59. McPherson, E.G. Selecting reference cities for i-Tree Streets. Arboric. Urban For. 2010, 36, 230-240.

60. Tooyama, J. Changes in energy conservation standards and future legislation. Nichias Technol. Time Signal 2013, 360, 6-9. Available online: https:/ / www.nichias.co.jp/research/technique/pdf/360/01.pdf (accessed on 25 February 2021).

61. Kyoto Residential Area Ranking. Available online: https:// sumaity.com/town/ranking/kyoto/living/?page=2 (accessed on 30 September 2020).

62. Hirabayashi, S. i-Tree Eco Precipitation Interception Model Descriptions. 2013. Available online: https://dev.itreetools.org/ documents/61/iTree_Eco_Precipitation_Interception_Model_Descriptions.pdf (accessed on 25 February 2021).

63. Wang, J.; Endreny, T.A.; Nowak, D.J. Mechanistic simulation of tree effects in an urban water balance model. J. Am. Water Resour. Assoc. 2008, 44, 75-85. [CrossRef]

64. McPherson, E.G.; Rowntree, R.A. Using structural measures to compare twenty-two US street tree populations. Landsc. J. 1989, 8, 13-23. [CrossRef]

65. Richards, N.A. Diversity and stability in a street tree population. Urban Ecol. 1983, 7, 159-171. [CrossRef]

66. Nowak, D.J.; Hirabayashi, S.; Bodine, A.; Greenfield, E. Tree and forest effects on air quality and human health in the United States. Environ. Pollut. 2014, 193, 119-129. [CrossRef]

67. Peper, P.J.; McPherson, E.G.; Mori, S.M. Equations for predicting diameter, height, crown width, and leaf area of San Joaquin Valley street trees. J. Arboric. 2001, 27, 306-317.

68. Fujii, E. Street Trees Contribute to the City: Walking on the Marathon Course of the Tokyo Olympics; Iwanami Shoten: Tokyo, Japan, 2019; pp. 135-140.

69. McPherson, E.G.; Simpson, J.R. A comparison of municipal forest benefits and costs in Modesto and Santa Monica, California, USA. Urban For. Urban Green 2002, 1, 61-74. [CrossRef]

70. Soares, A.L.; Rego, F.C.; McPherson, E.; Simpson, J.; Peper, P.; Xiao, Q. Benefits and costs of street trees in Lisbon, Portugal. Urban For. Urban Green 2011, 10, 69-78. [CrossRef]

71. Shoda, T.; Imanishi, J.; Shibata, S. Growth characteristics and growth equations of the diameter at breast height using tree ring measurements of street trees in Kyoto City, Japan. Urban For. Urban Green 2020, 49, 126627. [CrossRef] 
72. Hooper, L.G.; Kaufman, J.D. Ambient Air Pollution and Clinical Implications for Susceptible Populations. Ann. Am. Thorac. Soc. 2018, 15, S64-S68. [CrossRef] [PubMed]

73. Lin, J.; Kroll, C.N.; Nowak, D.J. Ecosystem Service-Based Sensitivity Analyses of i-Tree Eco. Arboric. Urban For. 2020, 46, 287-306. [CrossRef] 